\title{
La casación civil: mito y realidad. \\ Proyecto de ley modificatorio
}

\section{Aníbal Quiroga León}

"Abolidos por el Código Napoleónico la absurda prohibición de interpretación judicial y el referé legislatif, y puesta la interpretación de la ley en orden al caso singular controvertido entre los oficios esenciales del Juez, la Casación -que tomó el nombre de Cour, en lugar del de Tribunal, a partir del Senado Consulto del 28 Floreal del año XII-, extendió su control, que antes se limitaba a la contravención expresa de la ley, a la interpretación errónea y a la falsa aplicación de la ley, hasta llegar a los errores de derecho In Iudicando".

Piero Calamandrei La Cour de Cassation

\section{Antecedentes}

El Recurso Extraordinario de Casación tiene su verdadero origen en el Derecho francés, y no en el Derecho romano, como algunos sostienen, con evidente error llevados por el desconocimiento y engañados por el antecedente etimológico latino (Casare=anular); pues surge a finales del siglo XVIII con la instalación del Tribunal de Cassation ${ }^{1}$, donde la pacífica doctrina del Derecho Procesal encuentra antecedentes en el antiguo Conseil des Parties, cuya finalidad era la de ser un organismo que otorgaba a los ciudadanos la garantía del pleno respeto a la ley como máxima expresión de la voluntad popular.

Esta institución fue impulsada desde los albores de la Revolución francesa y en la plena formación del moderno Estado de Derecho, y

1 Leonardo Prieto - Castro.- Derecho Procesal Civil; Vol 1; Ed. Tecnos, Madrid, 1984, 3ª Ed. pp. 262 y ss. 
tenía en aquella época una naturaleza marcadamente política, puesto que fue creada como un órgano del Poder Legislativo a fin de ejercer la función de control de los jueces anulando las sentencias en dernier ressort (último grado). De allí la denominación de «Recurso Extraordinarion, sobre el principio de que al contener la sentencia judicial una contravención expresa de la ley no podía subsistir por encima de ésta. Al ser un órgano político en su origen, nunca pudo ingresar a conocer el mérito del asunto (el fondo o Meritum Causae), de modo que necesariamente se producía el reenvío del fallo de la instancia política a la justicia ordinaria para su reformulación sobre una distinta interpretación de la ley, cuya pauta era entonces marcada por el Tribunnel de Cassation. El objetivo era evitar que los jueces del Poder Judicial se excedieran en sus funciones jurisdiccionales, aunque esto fuera considerado como una invasión en los fueros parlamentarios y con ello se perdiera el respeto a la ley. Así, su principal función fue la de "fiscalizar las infracciones que atacaban a las leyes, las que negaban la existencia o incumbencia de una ley (contravention exprese au texte de la loi)»n. En efecto, como señala De la Rúa ${ }^{3}$ :

«El Tribunal de Cassation, al igual que el Conseil des Parties, representaba la suprema garantía de justicia frente a la violación de la ley. Sobre esto no cabe diferencias entre éllos. Desde luego que el Tribunal de Cassation, no fue exactamente idéntico al Conseil: "Nuevos eran los tiempos, nueva la idea del Estado, de la ley, de los sujetos, y nuevo debe ser necesariamente el órgano que concurriría a la afirmación de aquélla idea" ".

Por su parte, Calamandrei ${ }^{4}$ enseña que:

«El Tribunal de Cassation fue creado por Decreto de 27 de noviembre/lero. de diciembre de 1790 , para prevenir las desviaciones de los Jueces frente al texto expreso de la ley, lo que era

2 Referido a la "Contravención expresa al texto de la ley». N. del A.

3 Fernando De la Rúa.-El Recurso de Casación; Zavalia, Bs. As., 1968; pp.33 y 34.

4 Piero Calamandrei.- Casación Civil; EJEA, Bs. As., 1959. Ver también: Bruno Marchese,.- "La Casación de los Procesos Civiles por la Corte Suprema de Justicia»; Tesis, Mimeo, Fac. de Der. PUC del Perú, Lima, 1987. 
considerado como una intromisión en la esfera del Poder Legislativo, capaz de quebrantar la separación de los poderes que era piedra angular de la nueva concepción del Estado de Derecho; tal es así que en los primeros años de la Revolución se dio una ley que prohibía a los Jueces de interpretar las leyes, aún con eficacia limitada al caso concreto."

También Rivarola ${ }^{5}$ establece que:

«La Constituyente francesa, tuvo profunda influencia el pensamiento de Motesquieau, para quien "los jueces de la Nación no son más que la boca que pronuncia la palabra de la ley [...], de la que no pueden moderar ni la fuerza ni el rigor". En el gobierno republicano, -decía tambien Montesquieau- es propio de la Constitución que los Jueces se atengan a la ley literalmente [...]. Si los Tribunales no deben ser fijos, las sentencias deben serlo, a tal punto que no importe otra cosa que un texto preciso de la ley.

Si representara una opinión particular del Juez, se viviría en una sociedad sin saber los compromisos que en élla se contraen».

El Recurso de Casación nacido en el así en el Derecho francés de la era moderna (cuyo antecedente histórico más remoto quizás pueda ser forzado en el Derecho Romano Intermedio en la Querella Iniquitatis y en la Querella Nullitatis), con el paso del tiempo fue adquiriendo características diferentes, y prontamente fue asimilado por Poder Judicial desde el Poder Legislativo sobre mediados del siglo pasado, por medio de la metamorfosis del Tribunnel de Cassation a la Cour de Cassation (Corte de Casación), como bien lo explica De la Rúa ${ }^{6}$ :

«En la práctica antes que en la ley, se fue afirmando la verdadera fisonomía de la institución. El Tribunal fue transformándose en un verdadero Organo Jurisdiccional colocado en la cúspide" de las jerarquías judiciales.»

5 Mario Rivarola.- Enciclopedia Jurídica OMEBA; Driskill, Bs. As., 1954, T. II; p. 787.

6 Fernando De la Rúa.- Op. cit. 
Por su parte, y a este respecto, dentro de los alcances de la legislación comparada, Calamandrei?, señaló que:

«Para seguir la difusión de la casación en el mundo, pueden dividirse las legislaciones civiles en tres grupos: uno, el de las legislaciones europea y extraeuropea, a las cuales el sistema ha continuado siendo totalmente extraño (Inglaterra, Dinamarca, Danzing, Suecia, Noruega, Filandia, Rusia, Estados Unidos [...]; otro grupo acaso el más numeroso, en el cual la casación ha sido cogida fielmente en su forma francesa (Bégica, Holanda, Estonia, Luxemburgo, España, Grecia, Polonia, etc.); y finalmente un tercer grupo [...] para el que la dogmática del instituto es tal vez el más interesante, en los cuales, si no se han adoptado el nombre y las formas del recurso de casación concebido como querella de nulidad, se ha adoptado, sin embargo, un sistema que tiende, con formas procesales más modernas, a los mismos fines de unificación de la jurisprudencia, y para los cuales la casación es hoy en día viva y vital. Este es el sistema de la Revisión germánica (Alemania, Austria, Hungría, Suiza, etc.) [...]».

Los antecedentes del Recurso de Casación en el Perú se remontan, sin duda alguna, a su inicial inclusión en la Ley de Enjuiciamientos Civiles de $1852^{8}$ donde se le legisló sobre la base del «Recurso de

7 Piero Calamandrei,.- Op. cit.p. 39.

8 "También en dicho período se da inicio a una reorganización administrativa, municipal y judicial, existiendo consenso respecto de la necesidad de dotar al país de Códigos Nacionales -al mejor estilo europeo luego de la promulgación de los Códigos Napoleónicos[...]. La nueva codificación, pues, permitiría un adecuado marco legal para las transacciones privadas. Llegado el año 1851, se aprueban por Ley de 29 de diciembre, expedidas por el Presidente Rufino Echenique, los Códigos Civil y de Enjuiciamientos en Materia Civil, luego de que una Comisión Bicameral del Congreso nombrada al efecto el 7 de junio del mismo año había formulado sus propuestas. Se ordenaba la promulgación y publicación de los mismos a partir del 28 de julio del año siguiente, siendo su vigencia desde el día siguiente a su publicación.» En: Aníbal Quiroga León y Juan Monroy G.- "Las Excepciones en el Proceso Civil Peruano. Análisis y Alternativa. Proyecto Modificatorion; Tesis, Facultad de Derecho; PUC del Perú, Mimeo, Lima, 1982; p. 183. "[...] es bien interesante, como señala Basadre, que dos de los Códigos más importantes [...] se dan durante el período presidencial de Echenique (1851-1854), hijo de uno de los grandes hacendados de la costa y de tendencia conservadora, pero convencido de la necesidad del progreso material [...]» en: Fernando de Trazegnies,.- La Idea del Derecho en el Perú Republicano del Siglo XIX; Fondo Ed., PUC del Perú; Lima, 1980; p. 162. 
Nulidad» español que se adoptara el Real Decreto de 04 noviembre de 1838, al haberse traducido literalmente el término francés Casser por su acepción española de "anular»", y el Recurs de Cassation por su versión española literal de "Recurso de Anulación" o «Recurso de Nulidad", como finalmente lo denominó la Ley de Enjuiciamiento Civiles de España del siglo pasado, impronta de nuestro Código de Enjuciamientos Civiles de 1852. Sin embargo, este simple esfuerzo de entendimiento no siempre es adecuadamente realizado, y se trata de buscar diferencias donde hay más similitudes, instituciones diversas donde hay simplemente un problema de traducción legal e idiomática ${ }^{10}$.

Posteriormente, cuando en noviembre de 1911 se promulga el Código de Procedimientos Civiles, vigente desde el 28 de julio de 1912 hasta la entrada en vigencia del actual Código Procesal Civil (que tiene un Texto Único Ordenado) hace sólo poco más de seis años, se continuó bajo la misma denominación de Recurso de Nulidad que es, en puridad, una mera traducción del francés del Recurso de Casación, como sucedió con la legislación española de 1938, por lo que cabe afirmar que son en realidad conceptos sinónimos, constituyendo en esencia en el origen la misma institución procesal que hoy tenemos legislada en los arts. $384^{\circ}$ y siguientes del Código Procesal Civil de 1993.

Como ya lo señaláramos, la principal finalidad de este Recurso Extraordinario consiste en procurar corregir los errores del juzgamiento y los errores en el procedimiento (error in iudicando y error in

9 "La cassation est l'annulation d'un jugement d'un arret» (La casación es la anulación de un juzgamiento o de una sentencia), en: Diccionario Larousse, París, 1981, p.98.

10 «Etimológicamente casación proviene del latín. En su segunda acepción en el Diccionario de la Lengua Española es la derivación de cassare, de cassus: vano, nulo; y significa la acción de anular, abrogar, derogar. Denota, en definitiva una aplicación procesal como recurso, la acción y efecto de recurrir en juicio u otro procedimiento ara reclamar contra resoluciones, ora ante la autoridad que las dictó, ora ante alguna potra. El moderno recurso de casación es el que se interpone ante un Tribunal de orden Supremo contra los fallos definitivos o laudos dictados por una instancia inferior, en los cuales se presumen infringidas leyes o doctrina legal, o quebrantada alguna de las formas que dan garantías esenciales al procedimiento». En: Aníbal Quiroga León,.- «La Casación Civil y la Tutela Jurídica de las personas en la Jurisprudencia del Tribunal Constitucional Español»; Thémis Revista de Derecho No. 15, Ed. por estudiantes de la Fac. de Derecho de la PUC del Perú; I ima, 1989; pp. 15 y ss. 
procedendo que de modo unánime se refiere la doctrina) que se hayan cometido en agravio de los justiciables por los tribunales judiciales bajo la premisa de la violación o la desnaturalización del texto expreso de la ley, cuando en revisión hayan resuelto un proceso con la expedición de una sentencia definitiva o una sentencia interlocutoria que ponga fin a un proceso, cualesquiera sea el tipo de proceso judicial que la Teoría del Proceso reconoce en el moderno Derecho Comparado, a saber: (i) de conocimiento; (ii) ejecutivo; o (iii) cautelar ${ }^{11}$.

\section{Definición conceptual de la casación}

El Recurso de Casación, como ya se ha expuesto, no nace en Roma, ni en el Derecho Romano, sino en la Francia post-revolucionaria, con la finalidad de controlar la legalidad de los fallos judiciales, al entender que un fallo judicial alejado del texto de la ley sugería una inaceptable intromisión del Poder Judicial en el Legislativo, ya que de ese modo el juez con error en el juzgamiento (error in iudicando) se convertía, al interpretar de modo equívoco la ley, en "extraoficial e incompetentem legislador, produciendo un acto nulo. Como señala Calamandrei ${ }^{12}$, la Casación se propone como una querella nullitatis del Derecho Estatutario en la que el recurrente es el «accionante» de la Casación de modo diverso al recurso de apelación. El recurrente "combate" la sentencia nula con el instrumento de la Casación en la mano, y de allí la formalidad y las altas exigencias, así como la "carga de la prueba» con la que la ley grava a este medio extraordinario de impugnación. Siendo ambos recursos de impugnación -Apelación y Casación- medios de gravamen, el primero será «ordinario», ineludible para la ley y siempre exigible por el justiciable; en tanto que el segundo será extraordinario, discrecional para la ley y para el propio Tribunal de Casación. De hecho, el acceso a la Casación, o al Supremo Tribunal de Justicia no está reconocido en el Perú, ni en ningún tratado internacional en materia de Derechos Humanos como una garantía

11 Mauro Cappelletri.-El Proceso Civil en el Derecho Comparado; Breviarios de Derecho, EJA, Bs. As., 1973

12 Piero Calamandrei.- Estudios sobre el Proceso Civil; Bib. OMEBA, Bs.As., 1961, pp. 453 y ss. 
constitucional de la Administración de Justicia o como un Derecho Fundamental.

El original Tribunnel de Casation, que había reemplazado al antiguo Conseil des Parties, fue creado por Decreto del 27 de noviembre de 1790 para prevenir las desviaciones de los jueces frente al texto expreso de la ley, lo que fue considerado como una invasión del fuero judicial en el fuero parlamentario, único soberano de la ley. Esta intromisión quebrantaba la separación de poderes, por lo que la Revolución Francesa creó este Tribunal dentro del Poder Legislativo como un modo de control político de la actividad judicial. El culto a la ley, máxima expresión de la voluntad soberana del pueblo, justificaba el control parlamentario sobre la legalidad de las sentencias judiciales, de manera tal que detectada una nulidad (una casación), se disponía la remisión de la causa a la Corte de Justicia para su reformulación (reenvío).

Así, en su más remoto origen francés, como ya se ha señalado, el Tribunal de Casación era un órgano del Poder Legislativo, y ejercía sus funciones anulando las sentencias en último grado (finales, de último grado o de dernier ressort) que tuviesen una contravención expresa al texto de la ley y sin pronunciamiento de fondo, disponiendo el reenvío al Tribunal de Justicia como ya queda dicho, teniendo por tanto como principal función en este control de la legalidad, una función de control negativo ${ }^{13}$.

«El carácter puramente negativo de este Tribunal, así como la plena libertad del Juez de reenvío de rebelarse contra sus censura, fueron lógicas consecuencias del carácter no judicial de este órgano de control, cuyo influjo positivo sobre el ejercicio de la jurisdicción hubiera aparecido como una extra-limitación en el terreno de la función judicial $y$, por consiguiente, como una violación del principio de la separación de poderes, de que fueron los revolucionarios rígidos custodios». ${ }^{14}$

Este carácter negativo se entendía por el carácter puramente devolutorio vía reenvío que hacía este Tribunal del control de la lega-

13 Piero Calamandrei.- La Casación Civil; Bib. Jurídica, Bs.As., 1959, pp. 22 y ss.

14 Op. cit. p. 34. 
lidad, señalando desde afuera de la labor jurisdiccional cuál era el «verdadero" sentido de la ley, en tanto que por carácter positivo se entendía el Tribunal con facultad de pronunciamiento sobre la materia de la controversia.

Lo que sucedió en la práctica, con el paso del tiempo, fue que el Tribunal de Casación fue afirmando su verdadera fisonomía, y transformándose en verdadero órgano jurisdiccional colocado en la cúspide del vértice superior de las jerarquías judiciales ${ }^{15}$.

Así, son dos las características judiciales que adoptó el Recurso de Casación:

1. El control de la legalidad en el juzgamiento, o el error in-iudicando, que se define también como el error en la falsa o errónea interpretación de la ley o error en el juzgamiento por la aplicación de la norma material; $y$,

2. El control de la legalidad en el procedimiento, o error in-procedendo, que se define como el error por quebrantamiento esencial de forma y que constituya violación del debido proceso legal.

3. Asimismo, siendo lo anterior las fuentes del recurso de casación, además del control de la legalidad, una es la ulterior finalidad del Supremo Tribunal cuando actúa como Corte de Casación: la nomofilaquia o la necesaria unificación del criterio jurisprudencial a nivel nacional en la aplicación de la ley material y ley procesal.

Por ello mismo es que la Casación es siempre subsecuente y ulterior al recurso ordinario de apelación, siendo por tanto extraordinaria, y dos son los requisitos esenciales de la misma:

1. La fundamentación explícita del agravio, y sus verdadera existencia; $y$,

2. La admisibilidad discrecional que de su procedencia haga, en función de lo anterior, por parte del Tribunal o Corte de Casación.

La Casación, también, ha evolucionado en su fase jurisdiccional de su forma tradicional (control de legalidad y posterior reenvío), a una 
suerte de Casación Moderna, esto es, al Recurso de Casación sin Reenvío (Cassation sans reenvoi), que se dispondrá discrecionalmente por el juzgador, permitiéndole a éste, sin ser instancia, ingresar en la relación material o en la relación procesal materia del juzgamiento, y producir la adecuada corrección sin proponer el reenvío en aras de la celeridad y la economía procesal.

Finalmente, la Constitución de 1993 (Art. 202, Inc. 2) y la Ley Orgánica del Tribunal Constitucional (Art. 41\%) ha generado una nueva denominación para este Recurso de Casación moderna, al denominarle -de modo impropio, creemos- "Recurso Extraordinario de Revisión de Fondo", sin reenvío, a esta "Casación Constitucional» que por sobre la apelación judicial impone la "Jurisdicción Negativa de la Libertad", al decir de Cappelletti ${ }^{16}$.

\section{Causales de procedencia del Recurso de Casación}

El Art. 3840 del Código Procesal Civil define lo antes señalado, al referir que los fines de la Casación son básicamente dos: la correcta aplicación e interpretación del "derecho objetivo" (sic), es decir, de la ley material; al mismo tiempo que lograr con ello, y por ello, la unificación de la jurisprudencia nacional por la Corte Suprema de Justicia de la República. Así, el Art. $384^{\circ}$ ya citado dice a la letra:

"Art. 3840.- Fines de la casación.- El recurso de casación tiene por fines esenciales la correcta aplicación e interpretación del derecho objetivo y la unificación de la jurisprudencia nacional por la Corte Suprema de Justicia."

Por otro lado, el Art. 385 del propio Código Procesal Civil señala las resoluciones judicial que pueden ser objeto del Recurso de Casación, precisando lo siguiente:

16 Mauro Cappelletti; cit. Aníbal Quiroga León.- «Una aproximación a la Justicia Constitucional: El Modelo peruano»; En: Sobre la Jurisdicción Constitucional, Aníbal Quiroga León - Compilador; Fondo Editorial, PUC del Perú, 1990; pp. 147 y ss. 
"Art. $385^{\circ}$.- Resoluciones contra las que procede el recurso.Sólo procede el recurso de casación contra:

1 Sentencias expedidas en revisión por las Cortes Superiores;

2 Los autos expedidos por las Cortes Superiores que, en revisión, ponen fin al proceso; $y$,

3 Las resoluciones que la ley señale. »

Cabe anotar que, salvo la disposición que expresamente refiere como norma de conexión a una disposición legal imperativa, el principio general es que la procedencia del Recurso de Casación sólo resultará procedente frente a un fallo de segunda instancia (sea sentencia final , sea sentencia interlocutoria) en que se ponga fin a la instancia y, por ende, al proceso, conforme lo establece el principio contenido en el Art. $11^{\circ}$ de la Ley Orgánica del Poder Judicial, la que a la letra dice:

"Art. 11\%.- Las resoluciones judiciales son susceptibles de revisión, con arreglo a ley, en una instancia superior.

La interposición de un medio de impugnación constituye un acto voluntario del justiciable.

Lo resuelto en segunda instancia constituye cosa juzgada. $\mathrm{Su}$ impugnación sólo procede en los casos previstos en la ley». (resaltado agregado)

Asimismo, lo anterior se complementa con el funcionamiento del Supremo Tribunal en la Casación sobre la base del propio texto constitucional (es una actividad jurisdiccional prevista en la Constitución Política del Estado) y desarrollada por la propia Ley Orgánica del Poder Judicial, como a la letra se señala:

«CONSTITUCIÓN POLÍTICA DEL ESTADO:

Art. $141^{\circ}$.- Corresponde a la Corte Suprema fallar en casación, o [...]» «LEY ORGÁNICA DEL PODER JUDICIAL:

Art. $28^{\circ}$.- La competencia de la Corte Suprema se extiende a todo el territorio de la República. Su sede es la Capital de la misma.

$[\ldots]$ 
Art. 32\%.- La Corte Suprema conoce de los procesos en vía de casación con arreglo a lo establecido en la ley procesal respectiva.» (resaltado nuestro).

Sin embargo, siendo lo anterior correcto, sobre los alcances de estas disposiciones se están presentando serios problemas de interpretación, paradójicamente de la propia ley material, por parte de la Corte Suprema de Justicia de la República en lo referido a los procesos cautelares, respecto de los cuales se ha negado, y se niega, a conceder como procedentes los recursos de casación interpuestos contra sendas providencias cautelares, impuestas o ratificadas de modo terminal por las cortes superiores luego de los correspondientes recursos de apelación, bajo la alegación que al ser "procesos cautelares" prevalece la interpretación de que dichas providencias no son de las que ponen fin a la instancia a tenor de lo dispuesto en el Art. 612 ${ }^{\circ}$ del Código Procesal Civil, en cuanto señala que es características de éstas ser "provisorias, instrumentales y variables" (sic); desconociendo lo expresamente dispuesto en la concordancia de los Arts. $611^{\circ}$ y $635^{\circ}$ del mismo texto legal, en cuanto se señala el contenido y objeto de una medida cautelar, su naturaleza "autónoma para el que se forma un cuaderno especial", dejando de lado la necesaria interpretación sistemática y teleológica respecto del Recurso de Casación, su base constitucional, y el hecho de ser el mecanismo de revisión natural y necesario por parte del Supremo Tribunal de Justicia del país. Más aún, tal proceder abstensivo y restrictivo terminaría vulnerando la propia ley procesal al determinar, por la vía de la interpretación restrictiva que esboza, una suerte de abrogación legislativa, ciertamente impropia, de modo tal que el contenido material del Art. $384^{\circ}$ del Código Procesal Civil, es decir, los fines esenciales de la Casación en la correcta aplicación de la ley material y de la unificación de la jurisprudencia por el más alto tribunal de justicia del país es procedente en todo el ámbito judicial, sin distinciones, con excepción de los procesos cautelares respecto de los cuales, por decisión de la Corte Suprema de Justicia de la República, ni hay control de legalidad, ni de la correcta aplicación de la ley material aún si se violan preceptos constitucionales en medidas cautelares, lo que no es ni imposible, ni infrecuente, ni, lastimosamente, hay a la fecha jurisprudencia unificada de la Corte Suprema de Justicia de la República. Dicho de otro modo, en todo lo que es la aplicación e 
interpretación de los Arts. 608 a 687 -Título IV del Código Procesal Civil referido al Proceso Cautelar- no existe, ni existirá de proseguir este criterio -que no encontramos acertado- jurisprudencia unificada de nuestro más alto tribunal de justicia.

Al lado de esto, el Art. $386^{\circ}$ del Código Procesal Civil, establece las causales por las que resultará procedente el Recurso de Casación. Así:

"Art. 386०.- Causales.- Son causales para interponer recurso de casación:

1. La aplicación indebida o la interpretación errónea de una norma de derecho material, así como de la doctrina jurisprudencial;

2. La inaplicación de una norma de derecho material o de la doctrina jurisprudencial; o

3. La contravención de las normas que garantizan el derecho a un debido proceso, o la infracción de las formas esenciales para la eficacia y validez de los actos procesales.

Está incluida en el inciso 1. la causal de aplicación indebida del artículo 138 de la Constitución».

Es pertinente anotar que en el caso de la causal señala en la parte final de esta norma legal, a la fecha debe considerarse referida al Art. $138^{\circ}, 2$ da. parte, de la Constitución Política del Estado, desde que se abrogó la referencia al Art. $236^{\circ}$ de la Constitución de 1979(D) como se consigna en la norma original, debido a la entrada en vigencia de la actual Constitución de 1993.

Esta norma legal también adolece de una seria construcción jurídica y sistemática, al "haber creado" tres causales donde la unánime doctrina del Derecho Comparado, y los orígenes del Recurso de Casación -incluyendo en ello la definición del Art. $384^{\circ}$ de su propio texto legal- hallan solamente dos.

En efecto, la norma del Art. $386^{\circ}$ del Código Procesal Civil parece inferir la existencia de tres causales, y la propia Corte Suprema de Justicia de la República todos los días se halla en serios problemas para dotar de contenido teórico e interpretativo a estas tres causales, pues una de ellas carece de sentido lógico. Veamos por qué.

No queda duda, para empezar, que los dos primeros incisos se refieren a errores in iudicando (error en el juzgar, la falsa o errónea 
aplicación o interpretación de la ley. En el inciso tercero es obvio que se refiere al error in procedendo (el quebrantamiento de la forma esencial del proceso). Dentro de los dos primeros, el Código Procesal Civil hace una escisión ilógica, pues resulta que es diferente el supuesto del inciso primero, referido a la aplicación o interpretación indebida (acción positiva) de una norma de derecho material; en tanto que en el inciso segundo se refiere a la inaplicación (acción omisiva, prefijo «in» de orden negativo) de una norma de derecho material. Pero resulta que en el quehacer judicial cotidiano, cuando se aplica indebidamente una norma de derecho material, resulta obvio que es por que se ha dejado de aplicar la norma de derecho material correcta, y es ello lo que precisamente otorga fundamento a la procedencia del Recurso de Casación. Y al mismo tiempo, cuando se inaplica la norma de derecho material correcta, como reza el inciso Segundo, es obvio que ello se ha hecho a costa de aplicar una norma incorrecta de derecho material. En definitiva, son el mismo supuesto normativo y no se ha hecho otra cosa que una escisión artificiosa de lo mismo, presentándose como diferentes lo que es igual, tan sólo por el engaño de utilizar en una parte un supuesto positivo y en la otra un supuesto negativo que, al final de cuentas, bien visto, no hacen otra cosa que dar el mismo resultado jurídico. De allí los problemas, serios por cierto, de la Corte Suprema de Justicia de la República y de los justiciables recurrentes para encontrarles significados diferentes y de hacer teoría en base al error.

Finalmente, se ha dicho en repetidas oportunidades que la gran diferencia entre el Recurso de Nulidad del Código de Procedimientos Civiles (D) y el Recurso de Casación del Código Procesal Civil está en que, en el primer caso, siempre se hacía una revisión del fondo de la cuestión controvertida (lo que no necesariamente era cierto), en tanto que en el segundo caso el examen de legalidad jamás toca el juzgamiento de fondo materia del recurso, incluyendo en ello la imposibilidad de revisar los criterios de valoración legal de los medios probatorios aportados al proceso.

Tal diferenciación tampoco es necesariamente cierta. En efecto, la versión final del Art. $1133^{\circ}$ del Código de Procedimientos Civiles (D) ${ }^{17}$ decía: 
"Art. $1133^{\circ}$.- Cuando la Corte Suprema declare haber nulidad, fallará al mismo tiempo sobre lo principal; pero sí la nulidad proviene de algunos de los vicios que anulan el juicio por constituir violación de alguna de las garantías de la administración de justicia y siempre que haya sido alegada en instancia inferior por la parte afectada, se limitará a reponer la causa al estado que corresponda".

En tanto que la versión del Art. 396 del Código Procesal Civil, en su Inc. 1ero. dice a la letra:

"Art. 396\%.- Sentencia fundada y efectos del recurso.- Si la sentencia declara fundado el recurso, además de declararse la nulidad de la sentencia impugnada, la Sala debe completar la decisión de la siguiente manera:

Si se trata de las causales precisadas en los puntos 1. y 2. del artículo $386^{\circ}$, resuelve además según corresponda a la naturaleza del conflicto de intereses, sin devolver el proceso a la instancia inferior.

[...]» (subrayado nuestro)

En tanto que la previsión de todo el Inc. 2 de esa misma norma legal es de quebrantamiento de forma con reenvío, con excepción del Inc. 2.5., que es de reenvío con rechazo liminar de la demanda.

Aparece evidente, pues, que por expreso mandato del Inc. lero. del Art. $396^{\circ}$ del Código Procesal Civil, la Corte Suprema de Justicia de la República, en caso de aplicar cualesquiera de los Incs. 1 y 2 del Art. $386^{\circ}$ del mismo texto legal -lo que demuestra con mayor contundencia aún su implicancia absoluta-, el supremo tribunal deberá resolver según corresponda a la naturaleza del conflicto de intereses, sin devolver el proceso a la instancia inferior (esto es, sin reenvío); reemplazando lo juzgado por los tribunales inferiores, por el nuevo juzgamiento de la ley aplicable del modo adecuado del supremo tribunal, con la consecuencia que ello traerá en las conclusiones legales en y el mismo fallo, es decir, resolviendo el fondo de la cuestión controvertida, qué duda cabe.

Conforme a lo previsto en el Inc. 3 del Art. $386^{\circ}$ del Código Procesal Civil, el Recurso de Casación también puede estar fundado en el 
defecto de forma o quebrantamiento de las formas esenciales del proceso (nótese del hincapié en el carácter necesariamente esencial de las formas quebrantadas), lo que en nuestro Derecho implica tanto la afectación al Debido Proceso Legal o a la Tutela Judicial Efectiva como conceptos equivalentes- ${ }^{18}$, y ahora contenidos en el Inc. 3 del Art. $139^{\circ}$ de la Constitución Política del Estado, y que a la letra dice:

\section{«CONSTITUCIÓN POLÍTICA DEL ESTADO.}

Art. $139^{\circ}$.- Son principios y derechos de la función jurisdiccional:

[...]

3.- La observancia del Debido Proceso y la Tutela Jurisdiccional. (Subrayado nuestro).

[...]”

"CÓDIGO PROCESAL CIVIL:

Art. $384^{\circ}$.- Fines de la casación.- El recurso de casación tiene por fines esenciales la correcta aplicación e interpretación del derecho objetivo y la unificación de la jurisprudencia nacional por Corte Suprema de Justicia.

Art. $385^{\circ}$.- Resoluciones contra las que procede el recurso.[...]

2.- Los autos expedidos por las Cortes Superiores que, en revisión, ponen fin al proceso; $y$;

[...]

Art. $387^{\circ}$ - - Requisitos de forma.- El recurso de casación se interpone:

1.- Contra las resoluciones enumeradas en el Art. 385;

2.- Dentro del plazo de 10 días, contados desde el día siguiente de notificada la Resolución que se impugna, acompañando el recibo de pago de la tasa respectiva; $y$,

[...]" (Subrayado agregado)

18 Aníbal Quiroga León.- Las Garantías Constitucionales de la Administración de Justicia»; en: La Constitución Diez Años Después; Fund. F. Naumann y Constitución \& Sociedad. Eds., Lima, 1989; pp. 289 y ss. 


\section{El proyecto}

\subsection{Exposición de motivos}

El principal objetivo de este proyecto importa -además de procurar aclarar el contenido de las normas en cuestión sobre la base de una adecuada aplicación dogmática- en primer término, y casi al mismo tiempo, la limitación del acceso del recurrente al supremo tribunal a los casos estrictamente necesarios, en la medida que se concibe al Recurso de Casación de naturaleza excepcional, discrecional para la ley, al margen de que además algunos asuntos deben ser excepcionalmente elevados en vía de consulta o ex-officio. Porque la regla general, con lo que se cumple plenamente la garantía constitucional de la instancia plural, es la del acceso irrestricto a un Tribunal de Alzada o Corte de Apelación, y no a una Corte de Casación, cuya génesis, desarrollo y finalidad son sustancialmente diferentes.

Tal tarea pasa necesariamente por la redefinición jurisdiccional del rol de la Corte Suprema de Justicia de la República. De conformidad con lo dispuesto en el Art. $141^{\circ}$ de la Constitución Política del Estado, corresponde al supremo tribunal conocer en casación las causas que, por arbitrio de la ley, le son elevadas de las cortes superiores. Pero también, por mandato de esa misma norma, le corresponde al supremo tribunal conocer en vía de instancia, sea de segunda instancia de las causas conocidas en primera instancia por las cortes superiores, sea en vía de primera instancia en las causas que le son originarias que, por excepcionalidad constitucional o legal, le compete conocer al propio supremo tribunal de modo directo y primigenio. No cabe duda que en estos dos últimos casos, el supremo tribunal no funciona como Corte de Casación, sino como Corte de Instancia.

Esa es, pues, nuestra primera tarea de reordenamiento. Al redefinir el rol verdadero de la Corte Suprema, al poder distinguir siempre y en cada lugar cuándo la Corte Suprema actúa como Corte de Casación -rol natural y de orden discrecional; y cuándo la Corte Suprema actúa como Corte de Instancia -rol excepcional y obligatorio-, podremos entonces controlar de mejor modo el número de los asuntos, y por ende de las causas, que llegarán por vía de Casación, de apelación o de primera instancia al supremo tribunal.

Sobre esto, hasta la fecha ha habido mucha inconexión y superposiciones. Hay casos naturales de Casación que han sido trata- 
dos como de instancia, y hay casos de instancia que han sido tratados como de Casación, y otros notoriamente omitidos y olvidados, dejando la puerta abierta a la saturación innecesaria del supremo tribunal.

Una Corte de Casación debe ser, por sus propia naturaleza y finalidad, excepcional, discrecional, informadora y controladora. Así, no todas las causas judiciales «deben" acceder al supremo tribunal para su control de legalidad. Tampoco existe, como garantía constitucional de la Administración de Justicia, el «Derecho a la Casación», pues tal no existe. La garantía constitucional del debido proceso se cumple con el agotamiento de la instancia plural, conforme lo preceptúa el Art. 11\% de la Ley Orgánica del Poder Judicial. La función de la Casación es fundamentalmente otra. Pero al lado de ello, y por ello mismo, se hace necesario distinguir con técnica y puntualidad los casos en que necesariamente, por la vía excepcional, la Corte Suprema deja su rol natural de Corte de Casación e ingresa a la vía de la "instancia» o a la vía de la "Suprema Revisión Administrativa», excepcionalmente las menores, pero necesarias de manejo y adecuada regulación.

Una de las principales causas del recargo en la labor jurisdiccional del supremo tribunal radica, sin duda alguna, y al lado del volumen aritmético de causas, en el desorden de las competencias que le han sido asignadas, a la par que el desconocimiento y falta de sistematicidad en las competencias asignadas. Así, se confunde el rol de la casación, con el de la instancia - tanto si es segunda o primera -, y con el de la revisión administrativa, por lo que se hace necesario dividir ello con claridad, de modo tal que de inmediato reordene este trabajo jurisdiccional, delimite los canales competenciales correspondientes y redefina qué y cómo debe actuar cada sala jurisdiccional del supremo tribunal en cada momento y lugar.

Se ha considerado que es indispensable empezar por esta necesaria redefinición normativa y conceptual para poder ordenar el trabajo que se habrá de distribuir. En ningún caso se trata de dar o derogar dos o tres normas que limiten o puedan válidamente regular el funcionamiento jurisdiccional de la Corte Suprema de Justicia de la República, pues con ello nada se solucionaría en estricto sentido y el resultado final sería aún insuficiente. De este modo, consideramos más útil al supremo tribunal y al necesario acceso ciudadano en la búsqueda del servicio jurisdiccional eficaz. 
Es por ello que este proyecto normativo, que pretende ser un instrumento de trabajo antes que una propuesta definitiva, abarca no sólo el tema de las distintas competencias del supremo tribunal, sino que necesariamente, por su rol piramidal, la redefinición del rol del supremo tribunal arrastra, si queremos ser consecuentes, la redefinición de los roles de las cortes superiores, de primera instancia y de las leyes procesales de las que se nutre principalmente el trabajo jurisdiccional del supremo tribunal. Por ello, además de las naturales referencias a la Ley Orgánica del Poder Judicial, necesariamente nos remitiremos también al Código Procesal Civil, a la Ley de Garantías Constitucionales, al Código de Procedimientos Penales, al Código Tributario, etc.; siempre en conexión con el rol y el funcionamiento jurisdiccional del supremo tribunal.

Ciertamente este proyecto es, como ya se ha dicho, una propuesta integral que pretende ser material de trabajo a la discusión clara, técnica y profunda que permita arribar a una normatividad acorde con el necesario mejoramiento normativo de la distribución del trabajo jurisdiccional de nuestra Corte Suprema de Justicia de la República.

En el Art. $1^{\circ}$ del Proyecto, se establece una definición del sentido de la «Ley de Casación» y del rol adecuado que corresponde a la Corte Suprema como Corte de Casación, principalmente, y excepcionalmente como Corte de Instancia cuando la ley así lo señale expresamente. Nos parece muy importante la primera expresión "Declárese de interés [...] " que debería marcar la pauta de la interpretación de todo el Proyecto.

El Art. 2o del Proyecto establece la modificación de los numerales de la Ley Orgánica del Poder Judicial que se consideran necesarios para la adecuada adaptación del Proyecto de modo integral, conforme se desarrollará más abajo.

La modificación del Art. $14^{\circ}$ de la Ley Orgánica del Poder Judicial se justifica en la necesidad de mejorar y adecuar la regulación de la judicial review que, por su propio mecanismo constitucional, termina siendo siempre actividad controlada por el Supremo Tribunal. Es necesario perfilar su contornos para evitar el error en sus aplicación, los abusos en la misma, y la corrupción que una anómala aplicación de ello ha producido en no pocas oportunidades. Por ello se especifica al final que, fuera de esas posibilidades, no se puede hacer "control judicial de la constitucionalidad de las leyes", mucho menos aún en medidas cautelares. 
El Art. $22^{\circ}$ de la Ley Orgánica del Poder Judicial procura terminar con la inacción de la Corte Suprema, en su labor jurisdiccional, en la aplicación de una suerte de Stare Decisis (decisiones jurisprudenciales de cumplimiento obligatorio), esto es, de jurisprudencia vinculante por parte de la Corte Suprema y para todo el ordenamiento jurídico nacional, evitando que por ello mismo el juez pueda ponerse, por error o por razones interesadas, por encima de la ley, cerrando el paso al funcionamiento de la "Sala Plena", y dejando la actividad de docencia por medio de la jurisprudencia en las propias salas jurisdiccionales.

El Art. $30^{\circ}$ de la Ley Orgánica del Poder Judicial establece la división flexible del trabajo jurisdiccional de la Corte Suprema, tomando como base la actual división del trabajo, pero dejando al margen del órgano de gobierno sus alteración a través de una "cláusula abierta" en razón al mejor funcionamiento del servicio judicial del supremo tribunal.

El Art. $31^{\circ}$ de la Ley Orgánica del Poder Judicial define los tres principales vías de acceso a la Corte Suprema por vía de la Casación, sea por el error en el juzgamiento, por el error en el procedimiento o quebrantamiento de forma, sea por mandato del «control judicial de la constitucionalidad".

El Art. $32^{\circ}$ de la Ley Orgánica del Poder Judicial define el funcionamiento excepcional de la Corte Suprema como Corte de Instancia, sea de segunda o primera instancia.

Los arts. $33^{\circ}, 34^{\circ}$ y $35^{\circ}$ de la Ley Orgánica del Poder Judicial definen con prolijo detalle todos los órdenes de competencia del supremo tribunal por razón de Casación, de Segunda Instancia y de Primera Instancia, en las diferentes especialidades vigentes y según se hallan conformadas a la fecha.

Los arts. $39^{\circ}, 40^{\circ}, 41^{\circ}, 42^{\circ}$ y $43^{\circ}$ de la Ley Orgánica del Poder Judicial definen lo mismo, por necesaria conexión con la labor del Supremo Tribunal, de las cortes superiores. Debe destacarse en este caso la atribución por razón de la especialidad del denominado «Amparo Laboral" y del "Amparo Agrario".

Los arts. $46^{\circ}, 47^{\circ}, 48^{\circ}, 49^{\circ}, 50^{\circ}, 51^{\circ}, 52^{\circ}$ y $53^{\circ}$ de la Ley Orgánica del Poder Judicial definen lo mismo, por conexión con las cortes superiores que a su vez alimentan a la Corte Suprema, de sus distintos órdenes competenciales, debiendo destacarse la uniformidad de sus denominación (eliminándose la sobrecalificación de «especializados» 
seguidos de la propia nomenclatura de la especialidad), la adecuación a la nueva terminología al Código del Niño y del Adolescente, y al Proyecto de Nuevo Código del Trabajo que, por lo demás, elimina la incertidumbre y dualidad en la competencia de los juzgados de Trabajo sólo para las reclamaciones de los trabajadores, y dejando aparentemente fuera las reclamaciones de los empleadores, así como las acciones contencioso-administrativas en materia laboral y agraria.

Los arts. $54^{\circ}, 55^{\circ}, 57^{\circ}$ y $59^{\circ}$ de la Ley Orgánica del Poder Judicial procuran racionalizar el trabajo de los juzgados de paz letrados, eliminándose de ellos la competencia laboral que tanta confusión ha traído, junto con la inseguridad y la ruptura de la especialidad laboral, dejando ello para el Juez de Trabajo de nivel de primera instancia. Hay una redefinición del rol del Juez de Paz Letrado.

El Art. $290^{\circ}$ de la Ley Orgánica del Poder Judicial procura traer una definición más clara que su predecesora, que algunas confusiones y no pocas desventuras han ocasionado en el Poder Judicial, generando inseguridad e incertidumbre por dualidad de interpretaciones, adoptándose una definición que involucra a la Corte Suprema con el Recurso de Casación, y que por lo demás ha sido la mayoritaria adoptada precisamente por el supremo tribunal hasta la fecha.

En el Art. $3^{\circ}$ del Proyecto, por necesaria subsidiariedad a los fines de este Proyecto, se propone la modificación de los arts. $384^{\circ}, 385^{\circ}$, $386^{\circ}, 390^{\circ}, 391^{\circ}, 394^{\circ}, 398^{\circ}$ y $542^{\circ}$ del TUO del Código Procesal Civil, para adecuarlo a la misma definición del Proyecto en cuanto al rol casatorio del Supremo Tribunal, concordando la concesión, inadmisibilidad y procedencia del recurso de casación, sus finalidades y aclarando sus necesaria redacción. Ello pasa por la eliminación del denominado «Pleno Casatorio» -en orden a la eliminación de la «Sala Plena» del supuesto de hecho normativo del Art. 22 de la Ley Orgánica del Poder Judicial, dejando la posibilidad de publicar jurisprudencia ilustrativa, antes que vinculante, a las propias Salas Jurisdiccionales. Ello incluye una redefinición de las competencias de los Juzgados, Cortes Superiores y Corte Suprema en las acciones contencioso-administrativas que tienen basamento constitucional. Asimismo, y de modo objetivo, se limita en principio el Recurso de Casación para los Procesos de Conocimiento, Abreviado de Conocimiento y de Ejecución, y dejando para los demás cerrada las puertas del Supremo Tribunal a menos que éste, discrecionalmente, determine su procedencia por la vía de que Queja de Derecho. 
En el Art. $4^{\circ}$ del Proyecto se propone la derogación de los Arts. $4^{\circ}$, $375^{\circ}$, última parte del $377^{\circ}, 400^{\circ}$ y la Décima Disposición Final del del Código Procesal Civil, por su manifiesta falta de fundamento, sobrecarga de trabajo que termina llegando al Supremo Tribunal, y ausencia de contenido técnico.

El Art. $5^{\circ}$ del Proyecto propone la modificación de los arts. $15^{\circ}$, $17^{\circ}, 28^{\circ}, 289^{\circ}, 290^{\circ}$ y $292^{\circ}$, así como la inserción del Art. $292^{\circ}$ BIS, del Código de Procedimientos Penales, en tanto entre en vigencia el Código Procesal Penal, a fin de colaborar con el rol de la Sala Penal de la Corte Suprema. Su texto se explica por sí mismo, y redefine el rol del Supremo Tribunal como Corte de Casación -proceso sumario-, y Corte de Apelación -proceso ordinario-.

El Art. $6^{\circ}$ del Proyecto procura adaptar los procesos penales en actual giro, y su denominación en el Código de Procedimientos Penales, a la que trae el propio Proyecto.

El Art. $7^{\circ}$ del Proyecto procura hacer lo propio respecto de los procesos laborales en actual giro, luego de la modificación de las competencias en dicha materia en los juzgados de paz letrados.

Los arts. $8^{\circ}$ y $9^{\circ}$ del Proyecto procuran la adaptación a la metodología y terminología del Proyecto de la normatividad procesal en materia de las acciones constitucionales de garantía, proponiendo la modificación de los arts. $14^{\circ}$ de la Ley No 25398 , y $1^{\circ}, 21^{\circ}, 22^{\circ}, 35^{\circ}$ y $36^{\circ}$ de la Ley $\mathrm{N}^{\circ} 23506$, además de propender a su actual denominación en la vigente Constitución de 1993.

En el Art. $10^{\circ}$ del Proyecto se propone la modificación de la regulación defectuosa del Código Tributario, pese a su modernidad, que habrá necesariamente de confundir y recargar el trabajo del Supremo Tribunal al mezclar los conceptos de la acción contencioso-administrativa, demanda contenciosa-administrativa y recurso extraordinario de revisión. Para ello se propone la eliminación del recurso extraordinario de revisión (que no tiene rango constitucional) y la racional normatividad que debe regir la acción contenciosa-administrativa contra los actos particulares de la administración tributaria, luego de la intervención del Tribunal Fiscal. Se propone un proceso ágil, sumario, de puro derecho $\mathrm{y}$, sobre todo, sin la desnaturalización que importa la legitimación que actualmente se confiere para ello de modo impropio a la administración tributaria. 
El Art. $11^{\circ}$ del Proyecto procura corregir el error de regulación que traen la primera parte del Art. $41^{\circ}$ y la Cuarta Disposición Transitoria de la Ley Orgánica del Tribunal Constitucional, dejando la presencia jerárquica del Supremo Tribunal de orden constitucional, y que permita su control sobre las acciones de garantía a nivel nacional, eliminándose una de las principales fuentes de corrupción judicial actual, al haberse omitido inconstitucionalmente el control jurisdiccional del Supremo Tribunal.

Los arts. $12^{\circ}$ y $13^{\circ}$ del Proyecto establecen la derogación tácita de rigor y la vigencia del Proyecto de Ley, así como la regulación de los Recursos Extraordinarios de Revisión que, ya concedidos, se hayan pendientes de ser resueltos, en tanto se instale el Tribunal Constitucional.

\subsection{Texto del proyecto de Ley}

\section{EL PRESIDENTE DE LA REPUBLICA;}

POR CUANTO:

El Congreso de la República ha dado la Ley siguiente:

EL CONGRESO DE LA REPUBLICA;

Ha dado la Ley siguiente:

Artículo $1^{\circ}$.- Declárese de interés para el Poder Judicial la racionalización y distribución ordenada del trabajo jurisdiccional de las Salas de la Corte Suprema de Justicia de la República, en cumplimiento del mandato constitucional de que constituya, fundamentalmente, una Corte de Casación y, excepcionalmente, una Corte de Instancia en los casos previstos en el texto expreso de la ley de la materia.

Artículo $2^{\circ}$.- Para el mejor cumplimiento de lo anterior, modifíquense los arts. $14^{\circ}, 22^{\circ}, 30^{\circ}, 31^{\circ}, 32^{\circ}, 33^{\circ}, 34^{\circ}, 35^{\circ}, 39^{\circ}$, Incs. 6 y 7 del $40^{\circ}$, Incs. 1 del $41^{\circ}, 42^{\circ}, 43^{\circ}, 46^{\circ}, 47^{\circ}, 48^{\circ}, 49^{\circ}, 50^{\circ}$, $51^{\circ}, 52^{\circ}, 53^{\circ}, 54^{\circ}, 55^{\circ}, 57^{\circ}, 59^{\circ}$ y $290^{\circ}$, modificado por la Ley $\mathrm{N}^{\circ}$ 26624, del Texto Único Ordenado de la Ley Orgánica del Poder Judicial, los que quedarán redactados del siguiente modo:

"Artículo $14^{\circ}$.- De conformidad con la segunda parte del Art. $138^{\circ}$ de la Constitución, cuando los Magistrados al momento de fallar el fondo de la cuestión de su competencia, en la sentencia o resolución que ponga fin al instancia, en cualquier clase de proceso o especialidad, encuentran que hay incompatibilidad insalvable entre su inter- 
pretación de una disposición constitucional y una con rango de ley que resulte necesariamente aplicable a la causa, resuelven esta con arreglo a la primera declarando al mismo tiempo la implicación de la norma legal en cuestión

La sentencias y resoluciones así expedidas serán elevadas en consulta a la Sala Constitucional de la Corte Suprema, si no fueran impugnadas. Lo son igualmente las sentencias en segunda instancia en la que se aplique este mismo precepto, aún cuando contra éstas no quepa recurso de Casación.

En todos estos casos los Magistrados se limitan a declarar la inaplicación de la norma legal por incompatibilidad constitucional, para el caso concreto, sin afectar su vigencia, la que es controlada en la forma y modo que la Constitución establece.

El mismo procedimiento regirá en el caso de normas de inferior jerarquía, siempre que tengan alcance general.

Fuera de estos específicos casos, incluyendo las providencias cautelares de cualesquiera naturaleza o denominación, los Magistrados están prohibidos de hacer revisión judicial de la constitucionalidad de las leyes, bajo responsabilidad."

"Artículo 22․- Las Salas de la Corte Suprema de Justicia de la República ordenan la publicación en el Diario Oficial "El Peruano" de las sentencias expedidas en casación, sean estas fundadas o infundadas, de los autos en que se declare la inadmisibilidad dicho recurso, y como de las sentencias expedidas en segunda instancia, las mismas que fijarán los criterios jurisprudenciales de la Corte Suprema.

Los principios de alcance general que aparezcan de los mismos, en cuanto no se opongan a la interpretación de la ley, podrán ser invocados por los Magistrados de todas las instancias, cualquiera sea su especialidad, así como por las partes que intervengan en los procesos de que se trate.

Las Salas de la Corte Suprema de Justicia de la República podrán apartarse de los principios precedentes en nueva interpretación de la ley en sentencias debidamente motivadas y que constituyan nuevos principios de alcance general."

"Artículo $30^{\circ}$.- El trabajo jurisdiccional de la Corte Suprema se distribuye en cinco Salas de cinco Vocales cada una, presididas por el de mayor antigüedad, dos en la especialidad Civil, dos en la especialidad Penal y una en la especialidad Constitucional y Social. 
El órgano de Gobierno del Poder Judicial podrá, en uso de su facultad reglamentaria, por Resolución motivada, crear más Salas jurisdiccionales, cambiar su especialidad, denominación y orden de competencia, y así alterar el número de Vocales que componen el colegiado en atención a los requerimientos del servicio y eficiencia jurisdiccional.

"Artículo 31․- La Corte Suprema conoce de los procesos en vía de recurso extraordinario de casación con arreglo a lo establecido en la presente ley y en las leyes procesales respectivas.

Como Corte de Casación, cualquiera sea la especialidad o materia del proceso de que se trate, son fines esenciales de la Corte Suprema de Justicia de la República:

1. La unificación del criterio jurisprudencial en la aplicación de la ley, corrigiendo los errores que en las Cortes Superiores o en los Juzgados de Primera Instancia se incurran en la falsa o errónea interpretación de la norma material que requiera ser aplicada al caso bajo juzgamiento;

2. La corrección de los errores de procedimiento, por quebrantamiento esencial de forma, que constituyan real afectación de las garantías constitucionales de la administración de justicia, del debido proceso legal y la tutela judicial efectiva, y siempre que no sea posible su subsanación sin la afectación de los principios ya enunciados; y,

3. La revisión del control constitucional de orden difuso de que trata la segunda parte del Art. $138^{\circ}$ de la Constitución y el Art. $14^{\circ}$ de esta ley, y que de modo exclusivo y excluyente compete al Poder Judicial.

Ninguna otra autoridad, fuera de la jerarquía jurisdiccional del Poder Judicial, de cualquier índole o especialidad, rango o jerarquía o materia, podrá hacer uso de esta facultad de control difuso de la constitucionalidad de las leyes, bajo sanción de nulidad y de la responsabilidad funcional que corresponda por irrogarse facultad que no le ha sido atribuida por la Constitución. Esta facultad se aplicará exclusivamente por las autoridades del Poder Judicial, en actuación jurisdiccional, en los términos que imperativamente indica la segunda parte del Art. $138^{\circ}$ de la Constitución y que desarrolla el Art. $14^{\circ}$ de la presente ley." 
"Artículo 32॰.- La Corte Suprema conoce, excepcionalmente, como órgano de primera instancia y de fallo, o de segunda instancia y de grado, los siguientes procesos:

a) De primera instancia:

1. Los originarios de la propia Corte Suprema que la ley expresamente señale; $y$,

2. Los demás señalados por ley expresa.

b) De segunda instancia:

1. Los iniciados en primera instancia en las Cortes Superiores;

2. Los procesos penales ordinarios cuyo juzgamiento oral se halla realizado en las Cortes Superiores; $y$,

3. Los demás señalados por ley expresa."

"Artículo 33․- Las Salas Civiles conocen:

a) Como Corte de Casación:

1. De los recursos de Casación de su competencia concedidos con arreglo a ley por las Cortes Superiores, contra las sentencias y demás resoluciones expedidas por éstas en Segunda Instancia y los que la propia Sala determinen discrecionalmente por la vía de la Queja de Derecho en atención a lo dispuesto en el Art. 31 de la presente Ley;

2. De las contiendas de competencia y de los conflictos de autoridad, conforme al Código Procesal Civil;

3. De la revisión del control constitucional de orden difuso de que trata la segunda parte del Art. $138^{\circ}$ de la Constitución y el Art. $14^{\circ}$ de esta ley en vía de casación o de consulta en los procesos civiles, de familia, de menores, del niño y del adolescente, mercantiles, y demás que correspondan a su competencia conforme a ley.

b) Como Corte de segunda instancia de grado:

1. De los procesos iniciados y fallados por las Cortes Superiores en las materias de su competencia; $y$,

2. De los procesos sentenciados en primera instancia originaria en la Sala Constitucional y Social de la propia Corte Suprema.

c) Como Corte de primera instancia de fallo:

1. Los procesos por responsabilidad civil contra los Vocales de la propia Corte Suprema y de las Cortes Superiores y contra Vocales del Consejo Supremo de Justicia Militar, Fiscal de la Na- 
ción, Fiscales Supremos y Superiores, y otros funcionarios, conforme a la Constitución y las leyes;

2. De los demás procesos que señale la ley."

"Artículo 34".- Las Salas Penales conocen:

a) Como Corte de Casación:

1. De los recursos de casación de su competencia concedidos con arreglo a ley por las Cortes Superiores, contra las sentencias y demás resoluciones expedidas por éstas en segunda instancia y los que la propia Sala determine discrecionalmente por vía de la queja de derecho en atención a lo dispuesto en el Art. 31 de la presente ley;

2. De las contiendas de competencia, transferencia de competencias y de los conflictos de autoridad, conforme a la ley procesal penal de la materia; $y$,

3. De la revisión del control constitucional de orden difuso de que trata la segunda parte del Art. $138^{\circ}$ de la Constitución y el Art. $14^{\circ}$ de esta ley en vía de casación o de consulta en los procesos penales de su competencia conforme a ley.

b) Como Corte de segunda instancia de grado:

1. De los recursos de apelación concedidos por las Cortes Superiores contra las sentencias y resoluciones expedidas éstas en primera instancia en los procesos ordinarios y en los juzgamientos orales;

2. De la investigación y juzgamiento de los delitos que se imputan contra los funcionarios comprendidos en los arts. $99^{\circ}$ y $100^{\circ}$ de la Constitución, Fiscales y Vocales Superiores, miembros del Consejo Supremo de Justicia Militar y contra los demás funcionarios que excepcionalmente señale la ley;

3. De las extradiciones activas y pasivas; $y$,

4. De los demás procesos previstos en la ley."

"Artículo 35․- La Sala Constitucional y Social conoce:

a) Como Corte de Casación:

1. De los recursos de casación de su competencia concedidos con arreglo a ley por las Cortes Superiores, contra las sentencias y demás resoluciones expedidas por éstas en segunda instancia en las acciones contenciosa-administrativas y las que la propia Sala 
determine discrecionalmente por vía de la queja de derecho en atención a lo dispuesto en el Art. $31^{\circ}$ de la presente ley;

2. De los recursos de casación constitucional de su competencia concedidos con arreglo a ley por las Cortes Superiores, contra las sentencias y demás resoluciones expedidas por éstas en segunda instancia de las acciones constitucionales de Hábeas Corpus, Amparo, Hábeas Data y Acción de Cumplimiento y los que la propia Sala determine discrecionalmente por vía de la queja de derecho en atención a lo dispuesto en el Art. $31^{\circ}$ de la presente ley;

3. De los recursos de casación en materia Laboral y Agraria concedidos por las Salas Laborales y Agrarias de las Cortes Superiores, cuando la ley expresamente lo señala y los que la propia Sala determine discrecionalmente por vía de la queja de derecho en atención a lo dispuesto en el Art. $31^{\circ}$ de la presente ley;

4. Del recurso de casación en las acciones de expropiación, cuando ello sea concedido por las Cortes Superiores, conforme a ley, sin perjuicio de la facultad discrecional que la propia Sala determine por vía de la queja de derecho en atención a lo dispuesto en el Art. $31^{\circ}$ de la presente ley; y,

5. De las contiendas de competencia y de los conflictos de autoridad que le son propios;

6. De la revisión del control constitucional de orden difuso de que trata la segunda parte del Art. $138^{\circ}$ de la Constitución y el Art. $14^{\circ}$ de esta ley en vía de casación, casación constitucional o de consulta en los procesos administrativos, constitucionales, laborales, agrarios y de cualquier otra especialidad que además correspondan a su competencia conforme a ley.

b) Como Corte de segunda instancia de grado:

1. De los recursos de apelación concedidos por las Cortes Superiores contra las sentencias y resoluciones expedidas éstas en primera instancia en los procesos constitucionales de Amparo, Hábeas Corpus, Hábeas Data y Acción de Cumplimiento, Acción Popular y en las acciones contencioso-administrativas que ellas conocen en primera instancia conforme a la ley de la materia;

2. De los recursos de apelación contra las sentencias y demás resoluciones concedidos por la Sala Civil de la Corte Suprema en los procesos por responsabilidad civil en los casos señalados en el inciso c), apartado 1 del artículo $33^{\circ}$ de esta ley; 
3. De los recursos de apelación contra las sentencias y demás resoluciones concedidos por la Sala Penal de la Corte Suprema en los procesos penales de que trata el Inc. b), apartado 2 del Art. $34^{\circ}$ de esta ley; $y$,

4. En los demás asuntos que establece la ley para los efectos de la segunda instancia de las causas administrativas, constitucionales, laborales, agrarias y sociales.

c) Como primera instancia de fallo:

1. En primera instancia de las acciones contencioso-administrativas, en los casos que la ley de la materia así lo establezca;

d) Como última instancia de revisión administrativa:

1. De los recursos de revisión administrativa frente a las resoluciones del Tribunal Fiscal, Superintendencia de Banca y Seguros, Contraloría General de la República, Banco Central de Reserva y demás instituciones administrativas, autónomas o no, respecto de las cuales la ley conceda expresamente recurso de revisión, el mismo que se denominará y conocerá como "Recurso de Revisión Administrativa".

En tales casos, la Sala Constitucional y Social procederá como suprema instancia administrativa, decidiendo el proceso administrativo según corresponda.

Resuelto el mismo, queda expedito el derecho del reclamante para proceder conforme a lo dispuesto en el Art. $148^{\circ}$ de la Constitución, y en concordancia con lo dispuesto en el Art. $23^{\circ}$ de esta ley, y ante la autoridad judicial competente, conforme a ley."

"Artículo 39०.- Las Salas de las Cortes Superiores resuelven en segunda y última instancia, con las excepciones que establezca expresamente la ley para el recurso de casación."

“Artículo 40.- Las Salas Civiles conocen:

[...]

6. De los recursos de apelación contra las resoluciones expedidas por los Ejecutores Coactivos, conforme a ley; y,

7. De los demás procesos que establece la ley."

"Art. 41".- Las Salas Penales conocen:

[...] 
1. Del juzgamiento oral y sentencia en primera instancia de los procesos ordinarios y los establecidos por la ley [...];"

"Art. 42".- Las Salas Laborales conocen:

1. En grado de apelación, las causas resueltas en primera instancia, por los Juzgados de Trabajo;

2. En grado de impugnación de los laudos arbitrales expedidos en un procedimiento de negociación colectiva;

3. En primera instancia, las acciones contencioso-administrativas y de la acción popular, en materia laboral, conforme a ley;

4. En primera instancia de las acciones constitucionales de Amparo, Hábeas Data y Acción de Cumplimiento, cuando la afectación de los derechos provenga de una orden judicial de un Magistrado Laboral, cualquiera sea su jerarquía, los archivos se encuentren en la especialidad laboral del Poder Judicial o la autoridad que deba cumplir lo que se le requiere pertenezca a la especialidad laboral del Poder Judicial, conforme al Art. $1^{\circ}$ de la Ley $\mathrm{N}^{\circ} 26301$;

5. De las contiendas de competencia promovidas entre Juzgados de Trabajo del mismo Distrito Judicial y entre éstos y otros Juzgados de distinta especialidad de su jurisdicción territorial;

6. De los conflictos de autoridad entre los Juzgados de Trabajo y autoridades administrativas en los casos previstos por la ley;

7. De las quejas de derecho por denegación del recurso de apelación;

8. De las contiendas de competencia elevadas por el Juez de su circunscripción, que hubiere promovido un Juez de otro Distrito Judicial; $y$,

9. De los demás asuntos que establece la ley."

"Artículo 430.- Las Salas Agrarias conocen:

1. En grado de apelación, los procesos resueltos por los Juzgados Agrarios;

2. En primera instancia, las acción contencioso-administrativa y la acción popular, en materia agraria, conforme a ley.

3. En primera instancia de las acciones constitucionales de Amparo, Hábeas Data y Acción de Cumplimiento, cuando la afectación de los derechos provenga de una orden judicial de un Magistrado Agrario, cualquiera sea su jerarquía, los archivos se encuentren en la especialidad agraria del Poder Judicial o la autoridad que deba cum- 
plir lo que se le requiere pertenezca a la especialidad del Poder Judicial, conforme al Art. $1^{\circ}$ de la Ley $N^{\circ} 26301$;

4. De los conflictos de autoridad entre Juzgados Agrarios y autoridades administrativas, en los casos previstos por la ley;

5. De las contiendas de competencia entre Juzgados Agrarios o entre éstos y otros Juzgados de distinta especialidad de su jurisdicción territorial;

6. De las quejas de derecho por denegatoria del recurso de apelación; $\mathrm{y}$,

7. De los demás asuntos que señala la ley."

"Artículo $46^{\circ}$.- Son Juzgados de primera instancia, las siguientes especialidades:

1. Juzgados Civiles;

2. Juzgados Penales;

3. Juzgados de Trabajo;

4. Juzgados Agrarios; $\mathrm{y}$,

5. Juzgados de Familia.

El órgano de gobierno de la Corte Suprema, atendiendo a las necesidades del servicio judicial y a la carga procesal, puede crear otros Juzgados de primera instancia de distinta especialidad a los antes señalados, definiendo su competencia.

En los lugares donde no hay Juzgados de una determinada especialidad, el despacho es atendido por un Juzgado Mixto, con la competencia que señale el órgano de gobierno del Poder Judicial.

Los Juzgados de primera instancia se denominan: "Juzgado [...]" sucediéndole directamente la denominación de la especialidad de que se trate y la provincia de su ubicación, antecediéndole el cardinal que corresponda salvo lo dispuesto en el párrafo anterior, en cuyo caso se denominará "Juzgado Mixto de [...]" con la mención a la provincia de su ubicación.

Todos los Juzgados antes señalados tienen la misma jerarquía."

"Artículo 470.- En cada Provincia hay cuando menos un Juzgado de especialidad determinada o Mixto. Su sede es la Capital de la Provincia y su competencia provincia, salvo disposición distinta de la ley o del Consejo Ejecutivo del Poder Judicial. Si son más de uno de la misma especialidad, se distinguen por numeración cardinal correlativa. 
El órgano de gobierno Distrital organiza el sistema de distribución de causas entre Juzgados de la misma especialidad."

"Artículo 48\%.- Hay Jueces de primera instancia de especialidad determinada o Mixtos, y supernumerarios en las Provincias, a razón de uno por cada seis Jueces de esa jerarquía, a quienes reemplazan en caso necesario."

"Artículo 49०.- Los Juzgados Civiles conocen:

1. De los asuntos en materia civil, familiar y mercantil que no sean de competencia de otros Juzgados de especialidad determinada ;

2. De las Acciones de Amparo, Hábeas Data y de Cumplimiento, conforme a ley, que no sean de competencia de otros Juzgados de especialidad determinada ;

3. De los asuntos que les corresponden a los Juzgados de Familia, de Trabajo y Agrario, en los lugares donde no existan éstos;

4. De los asuntos civiles contra el Estado, en las sedes de los Distritos Judiciales;

5. En grado de apelación los asuntos de su competencia que resuelven los Juzgados de Paz Letrados y los Juzgados de Paz No Letrados, donde no existan aquéllos, conforme a ley; y,

6. De los demás asuntos que les corresponda conforme a ley."

"Artículo 50․- Los Juzgados Penales conocen:

1. De los procesos penales de su competencia, con las facultades y los trámites señalados por ley;

2. De las Acciones de Hábeas Corpus;

3. En grado de apelación, los asuntos de su competencia que resuelven los Juzgados de Paz Letrados y los Juzgados de Paz No Letrados en los lugares donde no existan aquéllos; y,

4. De los demás asuntos que les corresponda conforme a ley."

"Artículo 51․- Los Juzgados de Trabajo conocen:

1. Las acciones derivadas por pretensiones individuales o colectivas por conflictos jurídicos plantean los trabajadores o los empleadores, dentro del régimen laboral de la actividad privada, con vínculo contractual vigente o disuelto, o como consecuencia jurídica del mismo, conforme a la ley de la materia;

2. De las acciones en materia de Seguridad Social; 
3. De las diligencias preparatorias destinadas a obtener la prueba de algún derecho de carácter laboral;

4. De la ejecución de resoluciones administrativas, laudos arbitrales, que señala la ley; $y$,

5. De los demás asuntos que les correspondan conforme a ley."

"Artículo 52‥- Los Juzgados Agrarios conocen:

1. De los procesos ordinarios, sumarios, especiales o de cualquier otra denominación que correspondan a su especialidad, conforme a ley de la materia;

2. De los procesos de expropiación de predios rústicos;

3. De los procesos ejecutivos, por préstamos otorgados con fines agropecuarios o de comercialización de productos agrarios; y

4. De los demás asuntos que les correspondan conforme a ley."

"Artículo 53․- Los Juzgados de Familia conocen:

1. De la investigación, protección y asistencia de menores en estado de abandono, peligro moral y otras situaciones que señala la ley;

2. De la investigación y aplicación de medidas de protección en favor de menores, por actos reprobados por la ley; y

3. De los demás asuntos preventivos y tutelares que determina el Código del Niño y del Adolescente y conforme a ley."

"Artículo 54‥- Hay Juzgados de Paz Letrados para conocer asuntos civiles y penales en los Distritos que solos o unidos a otros, alcancen los volúmenes demográficos rurales y urbanos y reúnan los requisitos que establezca el órgano de gobierno del Poder Judicial. La sede del Juzgado es determinada por el órgano de gobierno Distrital respectivo."

"Artículo 55०.- La competencia territorial de los Juzgados de Paz Letrados la establece el órgano de gobierno del Poder Judicial.

El órgano de gobierno Distrital fija, además, el sistema de distribución de procesos entre los Juzgados de Paz Letrados cuando sea necesario.

Asimismo el órgano de gobierno Distrital, puede disponer la especialidad determinada de los Juzgados de Paz Letrados, cuando así convenga para la mejor administración de justicia, y lo justifique la carga procesal. 
Los Juzgados de Paz Letrados se denominan; "Juzgado de Paz Letrado de [...]" seguido del Distrito en que se halle ubicado, y antecedido del ordinal cuando ello corresponda."

"Artículo 57․- Los Juzgados de Paz Letrados conocen:

a) En materia civil:

1. De las acciones derivadas de actos o contratos civiles o comerciales, inclusive las acciones interdictales, posesorias o de propiedad de bienes muebles o inmuebles, siempre que estén dentro de la cuantía señalada por el órgano de gobierno del Poder Judicial;

2. De las acciones de desalojo conforme a la cuantía que establezca el órgano de gobierno del Poder Judicial;

3. De los procedimientos de jurisdicción voluntaria que establezca la ley, diligencias preparatorias y legalización de libros contables y otros que establezca el órgano de gobierno del Poder Judicial;

4. De las acciones relativas al derecho alimentario, con la cuantía y los requisitos señalados por el órgano de gobierno del Poder Judicial;

5. De las tercerías excluyentes de propiedad, derivadas de los procesos de su conocimiento. Si en éstas no se dispone el levantamiento del embargo, el Juez de Paz Letrado remite lo actuado al Juez Civil o Mixto que corresponda, para la continuación del trámite. En los otros casos levanta el embargo, dando por terminada la tercería;

6. De los asuntos relativos a indemnizaciones derivadas de accidentes de tránsito, siempre que estén dentro de la cuantía que establezca el órgano de gobierno del Poder Judicial;

7. De los procesos de ejecución hasta la cuantía que señale el órgano de gobierno del Poder Judicial; y,

8. De los demás que señala la ley.

b) En materia penal:

1. De los procesos por faltas, expidiendo fallo apelable ante el Juez Penal o Mixto que corresponda; $y$,

2. De los demás asuntos que señala la ley."

"Artículo 59\%.- Las resoluciones de Juzgados de Paz Letrados y Juzgados de Paz, son conocidas en grado de apelación por los respectivos Juzgados de la especialidad determinada o Mixtos, según corresponda." 
"Artículo $290^{\circ}$.- En todos los procesos, sin necesidad de intervención directa de su cliente, el Abogado puede presentar, suscribir y ofrecer todo tipo de escritos que autorice el ejercicio de una representación judicial general, con excepción de aquellos que impliquen el ejercicio de actos de disposición para los que se requiere poder expreso, especial o general, conforme a la ley de la materia.

No se incluye en esta representación judicial la facultad de interponer recursos ordinarios o extraordinarios de impugnación que, conforme al Art. $11^{\circ}$ de esta ley, constituye acto de disposición del justiciable sólo delegable por poder expreso."

Artículo $3^{\circ}$.- Asimismo, modifíquense los arts. $384^{\circ}, 385^{\circ}, 386^{\circ}$, $390^{\circ}, 391^{\circ}, 394^{\circ}, 398^{\circ}$ y $542^{\circ}$ del Código Procesal Civil, los que quedarán redactados del siguiente modo:

"Artículo 3840.- Fines de la casación.- Son fines de la casación en los procesos que regula el presente Código, los señalados en el Art. $31^{\circ}$ de la Ley Orgánica del Poder Judicial."

"Artículo $385^{\circ}$.- Resoluciones contra las que procede el recurso.Solo procede el recurso de casación contra:

1. Las sentencias expedidas en segunda instancia por las Cortes Superiores en los procesos de conocimiento, procesos abreviado de conocimiento y proceso de Ejecución.

En los demás procesos, sólo se podrá conceder recurso de Casación por vía de la Queja de Derecho, siempre que, denegado el recurso por la Corte Superior, se declare fundada la correspondiente Queja de Derecho por la Corte Suprema en uso a la facultad discrecional de que está investida de conformidad con lo dispuesto en el parágrafo 1) del Inc. a) del Art. $33^{\circ}$ de la Ley Orgánica del Poder Judicial;

2. Las resoluciones expedidas por las Cortes Superiores que, en grado de apelación, ponen fin al proceso; y

3. Las resoluciones que la ley señale."

"Artículo 386.- Causales.- Son causales para interponer Recurso de Casación:

1. El error en la aplicación indebida o inaplicación debida, o la falsa interpretación, de la norma de derecho material que corresponda, y que constituya insalvable error en el juzgamiento en al caso bajo juzgamiento; 
2. Los errores de procedimiento, por quebrantamiento esencial de forma, que constituyan real afectación de las garantías constitucionales de la administración de justicia, del debido proceso legal y la tutela judicial efectiva, o esencial para la eficacia y validez de los actos procesales, y siempre que no haya sido posible su subsanación sin la afectación de los principios ya enunciados; y,

3. La revisión del control constitucional de orden difuso de que trata la segunda parte del Art. $138^{\circ}$ de la Constitución y el Art. $14^{\circ}$ de la Ley Orgánica del Poder Judicial."

"Artículo 390.- Concesión del recurso.- La Corte Superior ante la que se interpone el recuso, apreciará el cumplimiento de los requisitos de forma de que trata el Art. $387^{\circ}$ y lo concederá procediendo a la elevación de los actuados en el término de diez días. El incumplimiento o ausencia de alguno de ellos dará lugar a la denegación del mismo."

"Artículo 3910.- Admisibilidad del recurso de casación. - Concedido el recurso de casación por la Corte Superior, y elevados los actuados, la Sala que corresponda de la Corte Suprema decidirá en el auto correspondiente su admisibilidad o inadmisibilidad, apreciando de oficio o a petición de parte, con plena facultad discrecional, el estricto cumplimiento de los requisitos de fondo de que trata el Art. $388^{\circ}$. El incumplimiento de alguno de ellos, o la ausencia de razonabilidad de los fines de la Casación conforme a lo dispuesto en el Art. 384º dará lugar al auto de inadmisibilidad debidamente motivado y la devolución de lo actuado por ante la Corte Superior de donde provenga, teniéndose por ejecutoriada la resolución contra la cual se interpuso el recurso."

"Artículo 394\%.- Actividad procesal de las partes. - Durante la tramitación del recurso ante la Corte Suprema, la actividad procesal de las partes se limitará a la presentación de informes escritos y la acreditación del cambio o designación de la representación procesal o de apoderados, la prueba de la ley extranjera y su sentido, cuando ello sea pertinente.

Se permitirá la presentación de textos legales, de doctrina o de jurisprudencia. Se prohibe la presentación de nuevos medios probatorios en la Corte Suprema en el trámite del recurso de casación.

Para la determinación discrecional de la admisibilidad o 
inadmisibilidad del recurso de casación no podrán las partes, ni sus abogados, solicitar informe oral.

La intervención del Ministerio Público, cuando ello sea pertinente, sólo se dispondrá una vez admitido el recurso de casación.”

“Artículo 398\%.- Multa por recurso no concedido, inadmisible o infundado.- Si el recurso fuese denegado por no haber sisado concedido o por ser declarado inadmisible, la Sala respectiva condenará a la parte que lo interpuso al pago de una multa no menor de tres ni mayor de diez unidades de Referencia Procesal.

Si concedido y admitido el recurso, la sentencia en grado no fuese casada, el recurso será declarado infundado en todos sus extremos, disponiéndose la ejecutoriedad del fallo recurrido y la parte que la interpuso pagará una multa equivalente a una Unidad de Referencia Procesal. Si la resolución materia del grado confirmaba en todos sus extremos la de primera instancia, la multa será de dos unidades de referencia procesal.

Si se declara fundado en todo o en parte el recurso, y por lo tanto, se casa en todo o en parte la sentencia materia del grado, la parte que lo interpuso quedará exonerada de toda multa.

El pago de la multa será exigido de oficio por el Juez de la ejecución del fallo."

"Artículo 542\%.- Competencia.- Es competente el Juez Civil del lugar donde se produjo el acto o se dictó la resolución administrativa de carácter particular.

Cuando la resolución objeto de la acción contencioso-administrativa es emitida por un órgano administrativo colegiado o autoridad unipersonal de carácter municipal o regional, o por los Organos del Gobierno de las Cortes Superiores, por las Salas Superiores en Facultad Administrativa, es competente en primera instancia la Sala Civil competente de la Corte Superior de Justicia del lugar que corresponda a donde se produjo el acto o se dictó la resolución administrativa de carácter particular.

Cuando la impugnación se refiere a Resolución Suprema de efectos particulares, o resoluciones de efectos particulares emanadas de las Asambleas Regionales, del Banco Central de Reserva, de la Superintendencia de Banca y Seguros, de la Contraloría General de la República, del Tribunal Fiscal o de los órganos de gestión de la Corte Suprema, o de los propios órganos jurisdiccionales de la Corte Supre- 
ma en función administrativa, es competente en primera instancia la Sala Constitucional y Social de la Corte Suprema de Justicia de la República."

Artículo $4^{\circ}$.- Deróguense los arts. $4^{\circ}, 375^{\circ}$, último párrafo del Art. $377^{\circ}, 400^{\circ}$ y la Décima Disposición Final del Texto Único Ordenado del Código Procesal Civil.

Artículo $5^{\circ}$.- Asimismo, modifíquense los arts. $15^{\circ}, 16^{\circ}, 17^{\circ}, 28^{\circ}$, $289^{\circ}, 290^{\circ}$ y $292^{\circ}$ del Código de Procedimientos Penales, y agréguese a dicho texto legal el Art. $292^{\circ}$-BIS, los que quedarán redactados del siguiente.

"Artículo 15\%.- La Sala Penal de la Corte Suprema de Justicia conocerá de las resoluciones expedidas por las Salas Penales de las Cortes Superiores de Justicia, contra las que se este concede el recurso de apelación o de casación, según sea el caso. Resolverá, igualmente, las quejas, cuestiones de competencia y de extradición, conforme a las leyes."

"Artículo $16^{\circ}$.- Corresponde a la Sala Penal de la Corte Suprema de Justicia de la República, y previas las formalidades que determina este Código en el Título respectivo, resolver el Recurso de Revisión Penal; y ejercitar administrativamente las facultades especiales de vigilancia en materia penal, sin perjuicio de las otras atribuciones que les acuerda la Ley Orgánica del Poder Judicial."

"Artículo $17^{\circ}$.- Para la instrucción y juzgamiento de los delitos a que se refiere el Inc. 4to. del Art. $34^{\circ}$ de la Ley Orgánica del Poder Judicial, la Corte Suprema observará el procedimiento establecido en este Código, constituyéndose para el efecto en la Sala Penal del Supremo Tribunal la Sala Penal Especial con tres Vocales que sigan en antigüedad al Vocal Penal de Instrucción, y designando como tal al Vocal Supremo menos antiguo de dicha Sala Penal.

Tales designaciones corresponden al Presidente de la Sala Penal del Supremo Tribunal, quien no intervendrá en este Juzgamiento.

El recurso de apelación contra las decisiones del Vocal Penal de Instrucción serán conocidas y resueltas por la Sala Penal Especial.

El recurso de apelación contra las decisiones de la Sala Penal Especial serán conocidas y resueltas por la Sala Constitucional y Social, conforme a la Ley Orgánica del Poder Judicial."

"Artículo 28․- La Sala Penal dirimirá la competencia o resolverá la excepción de jurisdicción, sin más trámite que la audiencia al Fiscal 
Superior. Si las copias remitidas se consideran insuficientes, puede el Tribunal pedir, por un breve término, la instrucción.

De la resolución de la Sala Penal, en caso de competencia o declinatoria de jurisdicción, procede el recurso de apelación.

Cuando se establece competencia entre jurisdicciones de diverso fuero, sobre el juzgamiento de un mismo delito o de delitos conexos, corresponde dirimirlas a las Salas Penales, si se trata de jueces instructores del mismo Distrito Judicial, y a la Sala Penal de la Corte Suprema, si se trata de jueces instructores de diverso distrito judicial o de competencias entabladas a la misma Sala Penal de que se trate."

"Artículo 289 .- Leída la sentencia, el acusado o el Fiscal Superior, podrán interponer recurso de apelación, pudiendo hacerlo en el acto o reservarse ese derecho hasta dentro de tres días siguientes de expedido el fallo, oportunidad en que sólo podrán hacerlo por escrito."

"Artículo $290^{\circ}$.- La parte civil puede interponer recurso de apelación, sólo por escrito, en el mismo término señalado en el Art. anterior y únicamente en cuanto al monto del a reparación civil, salvo el caso de sentencia absolutoria."

"Artículo 2920.- Procede el recurso de apelación la Sala Penal de la Corte Suprema:

1. Contra la sentencias expedidas por salas penales de las salas superiores en los procesos ordinarios; $y$,

2. Contra las resoluciones expedidas en primera instancia de las Salas Penales de las Cortes Superiores, y

3. Contra las demás resoluciones que permita la ley."

"Art. 292 .- BIS. Procede recurso de apelación ante las Sala Penales de la Cortes Superiores:

1. Contra la sentencia expedida en los Juzgados penales;

2. Contra la concesión de la condena condicional;

3. Contra los autos que resuelven excepciones, cuestiones previas, o prejudiciales;

4. Contra los autos o resoluciones definitivas expedidas por los jueces penales que extingan la acción o pongan fin al procedimiento o la instancia;

5. Contra las sentencias expedidas por los juzgados penales en las acciones de Hábeas Corpus;

6. En los casos que la ley confiere expresamente dicho recurso. En casos excepcionales de error en el juzgamiento o quebranta- 
miento de forma esencial que implique violación del debido proceso no subsanables, la sala penal de la Corte Suprema por vía de recurso de queja, podrá disponer que se conceda recurso de casación de las sentencias y resoluciones de las salas penales expedidas en segunda instancia, o de la aplicación de la segunda parte del Art. $138^{\circ}$ de la Constitución según lo desarrollado en el Art. $14^{\circ}$ de la Ley Orgánica del Poder Judicial.

Artículo $6^{\circ}$.- En tanto entre en vigencia el Código Procesal Penal, toda referencia al recurso de nulidad a que haga mención el Código de Procedimientos Penales como medio de impugnación de la sentencias y resoluciones expedidas por las Salas Penales en primera instancia, deberá entenderse como recurso de apelación.

Toda referencia que el Código de Procedimientos Penales haga a los "Tribunales Correccionales" deberán entenderse a las Salas Penales de la Corte Suprema de Justicia de la República.

Artículo $7^{\circ}$.- Los procesos laborales que se hallen sustanciando los Juzgados de Paz Letrados, serán elevados en el día y bajo responsabilidad a los Juzgados de Trabajo, en el orden de competencia que indique la Secretaría Ejecutiva de la Comisión Ejecutiva del Poder Judicial dentro del tercero día de vigencia de la presente ley.

Artículo $8^{\circ}$.- Modifíquese el Art. $14^{\circ}$ de la Ley No 25398, el mismo que quedará redactado del modo siguiente:

"Artículo $14^{\circ}$.- Cuando la acción de garantía resultase manifiestamente improcedente por las causales señaladas en los arts. $6^{\circ}$ y $37^{\circ}$ de la ley, o por su manifiesta improcedencia en cuanto al fondo o finalidad, o por falta de agotamiento de las vías previas, o por ausencia de legitimidad en el obrar, o por la ambigüedad de la demanda, el Juez debe rechazarlas de plano bajo responsabilidad. En tal caso, procede recurso de apelación con efecto suspensivo."

Artículo 90.- Agréguese al Art. $1^{\circ}$ de la Ley No 23506 el siguiente párrafo:

"Artículo 1\%.-

[...]

Son acciones constitucionales de garantía, la Acción de Hábeas Corpus, la Acción de Amparo, la acción de Hábeas Data, y la acción de Cumplimiento de conformidad con lo dispuesto en el Art. $200^{\circ}$ de la constitución." 
"Artículo 21\%.- El plazo para interponer el recurso de casación constitucional, es de dos días hábiles de notificado el fallo de la Corte Superior y sólo procede contra la denegación del Hábeas Corpus."

"Artículo 220.- La Sala Penal de la Corte Suprema fijará para la vista de la admisibilidad del recurso de casación constitucional dentro de los cinco días hábiles siguientes de recibidos los autos, y escuchados del Procurador Público, de ser el caso, del actor y sus defensores, y la parte emplazada. El plazo para la resolución no podrá ser mayor de cinco (5) días hábiles, bajo responsabilidad."

"Artículo 35․- Contra la resolución de la Corte Superior se puede interponer recurso de casación constitucional, dentro de los tres días de expedida la resolución Superior, dicho recurso, si cumple con los requisitos de forma y de fondo, será concedido y elevado el expediente a la Sala Constitucional y Social de la Corte Suprema de Justicia de la República."

"Artículo 36".- Elevados los autos a la Sala Constitucional y Social de la Corte Suprema, se seguirá el mismo trámite y se observarán los mismos plazos que los indicados en el Art. $22^{\circ}$ de la presente ley, con la excepción de la solicitud de Vista Fiscal una vez admitido el recurso de casación constitucional el Fiscal Supremo deberá emitir dictamen en un plazo no mayor de 5 días hábiles, bajo responsabilidad."

Artículo $10^{\circ}$.- Modifíquense los arts. $102^{\circ}, 157^{\circ}, 158^{\circ}, 159^{\circ}, 160^{\circ}$ y $161^{\circ}$ del Código Tributario aprobado por Decreto Legislativo No 816, los que quedarán redactados del siguiente modo:

"Artículo $102^{\circ}$--Jerarquía de las normas. Conflicto normativo.- $\mathrm{Al}$ resolver el Tribunal Fiscal deberá observar los principios de validez, legalidad y constitucionalidad de las normas aplicables al caso concreto, encontrándose vinculado a las mismas hasta que no sean controladas en la forma y modo que la Constitución establece.

En caso de conflicto normativo por razón del tiempo, materia, especificidad o jerarquía, el Tribunal Fiscal aplicará los criterios de interpretación e integración normativa comúnmente aceptados.

$[\ldots]$

TITULO IV

DE LAS ACCION CONTENCIOSO-ADMINISTRATIVA ANTE EL PODER JUDICIAL

Artículo $157^{\circ}$.- Acción Contencioso-Administrativa.- Lo resuelto por el Tribunal Fiscal agota la vía administrativa, constituyendo su resolu- 
ción final una que causa estado a los efectos del Art. $148^{\circ}$ de la Constitución.

Contra lo resuelto por el Tribunal Fiscal sólo el deudor tributario podrá interponer acción contencioso-administrativa, la que se regirá por las normas contenidas en el presente Título $y$, supletoriamente, por las del Código Procesal Civil y la Ley Orgánica del Poder Judicial; salvo el caso del Art. $112^{\circ}$ de la Ley de Normas Generales de Procedimientos Administrativos.

La demanda sólo podrá ser presentada por el deudor tributario, dentro del plazo de quince (15) días hábiles contados a partir del día siguiente de efectuada la notificación certificada de la resolución del Tribunal Fiscal al deudor tributario. Este plazo es de caducidad.

La demanda deberá contener tener peticiones concretas. Las que carezcan de estas, sean manifiestamente confusas o continentes de pretensiones absurdas deberán ser inadmitidas de plano, en resolución debidamente motivada. Su presentación, admisión y tramitación en ningún caso interrumpe la ejecución de los actos o resoluciones de la Administración Tributaria.

La demanda se interpondrá ante la Sala Constitucional y Social de la Corte Suprema de Justicia de la República, debiendo recaudarse a la misma, además de los requisitos de la ley de la materia, los establecidos en el Art. $158^{\circ}$ del presente Código y la constancia de la fecha cierta de sus notificación. Las que se interpongan fuera del plazo de caducidad indicado en el párrafo anterior, será no serán admitidas de plano señalándose esta causal. Cuando la determinación de la fecha de notificación deba ser objeto de prueba, determinada por la Sala que la demanda se interpuso vencido el plazo de caducidad, en resolución motivada se dará por concluido el proceso en el estado en que se encuentre o se determinará la improcedencia de la demanda si su estado es el de emitirse sentencia.

Tribunal Fiscal, en caso que el demandante cumpla con los requisitos de admisibilidad establecidos en el presente Título, a requerimiento de la Sala Constitucional y Social, solicitará la remisión de lo actuado a la autoridad a la Administración Tributaria correspondiente, la que elevará todo lo actuado dentro del plazo improrrogable de quince (15) días hábiles siguientes a la fecha cierta del requerimiento oficial, bajo responsabilidad funcional y administrativa. El Tribunal Fiscal remitirá lo actuado ante la Corte Suprema. 
La interposición de la demanda contencioso-administrativa determina la improcedencia por causal de vía paralela de cualesquiera Acción de Garantía Constitucional contra la Resolución del Tribunal Fiscal o por sobre los hechos o actos tributarios materia de su conocimiento.

Artículo $158^{\circ}$.- Requisitos de admisibilidad. Del deudor tributario.Para la admisión de la demanda contencioso-administrativa es, además, requisito esencial que el deudor tributario acredite el previo pago de la deuda tributaria o presente carta fianza bancaria por el monto de la misma, incluyendo gastos e intereses prudenciales.

Cuando se presente carta fianza bancaria, podrá solicitarse a la Sala Constitucional y Social oficie a la Administración Tributaria para la suspensión de la cobranza por el plazo de la misma, debiendo renovarse la carta fianza bancaria de modo previo a su vencimiento cada seis (6) meses por el mismo monto, debidamente actualizada a la fecha de la renovación.

La falta de renovación semestral de la Carta Fianza, de modo oportuno y antelado, dará lugar a la conclusión del proceso en el estado en que se encuentre y a la caducidad de la acción contencioso administrativa. En tal caso, la Sala Constitucional y Social en el día y de pleno derecho pondrá ello en conocimiento de la Administración Tributaria.

Artículo $159^{\circ}$.- Tramite, medios probatorios y medidas cautelares.Admitida la demanda a trámite por la sala Constitucional y Social, se oficiará al Tribunal Fiscal para la remisión de los actuados administrativos que dan origen a la causa, y se correrá traslado a la Administración Tributaria, sustanciándose la causa como Proceso Sumarísimo de puro derecho. Sin embargo, las partes podrán presentar, en cualquier estado del proceso, medios probatorios instrumentales públicos y privados, los que serán valorados con arreglo al Código Procesal Civil.

La defensa de la Administración Tributaria correrá a cargo del Procurador Público habilitado al efecto, a menos que se trate de entidad pública con personería jurídica propia, en cuyo caso la demanda deberá entenderse con su representante legal, sin perjuicio de notificarse, además, en tal caso al Procurador Público a cargo de los asuntos del Ministerio de Economía y Finanzas.

En todos los casos, además, deberá ponerse en conocimiento del Tribunal Fiscal la resolución admisoria o inadmisoria, la de caducidad del proceso y la sentencia que expida la Sala Constitucional y Social mediante oficio con transcripción de la resolución de que se trate. 
En esta acción judicial sólo se podrán solicitar y obtener, bajo sanción de nulidad, y responsabilidad funcional, medidas cautelares de naturaleza registral o inscribibles. En ningún caso podrá concederse como medida cautelar la exoneración total o parcial de la deuda tributaria materia del proceso.

Artículo $160^{\circ}$.- Informe oral y alegatos.- Concluida la Audiencia Única, las partes dispondrán de diez (10) días hábiles para formular sus alegatos escritos y solicitar el uso de la palabra a fin de informar oralmente, lo que se regirá por lo dispuesto en la Ley Orgánica del Poder Judicial.

Artículo $161^{\circ}$.- Dictamen Fiscal, resolución y apelación.- La Sala Constitucional y Social, expedita que sea la causa para ser sentenciada, solicitará dictamen fiscal ilustrativo.

Emitido dictamen fiscal, expedirá resolución en un plazo no mayor a treinta (30) hábiles con posterioridad a la vista de la causa.

Expedida sentencia, podrán las partes recurrir en apelación a la Sala Civil de la Corte Suprema de Justicia de la República, en el término de cinco días de notificada con fecha cierta.

La Sala Civil expedirá sentencia en segunda instancia, sin más trámite que el correspondiente dictamen fiscal y el plazo de alegatos e informe oral, si fuera solicitado, conforme a lo previsto en el artículo anterior.

La Sala Civil expedirá sentencia en segunda instancia, definitiva y con calidad de cosa juzgada material, en el mismo plazo que el señalado en el segundo párrafo del presente artículo.

Contra lo resuelto por la Sala Civil no cabe recurso ni acción ulterior alguna, ni le es aplicable lo previsto en el Art. $178^{\circ}$ del Código Procesal Civil.

Artículo $11^{\circ}$.- Modifíquense la primera parte de Art. $41^{\circ}$ y la Cuarta Disposición Transitoria de la Ley Orgánica del Tribunal Constitucional aprobada por Ley No 26435, la misma que quedará redactada en los términos siguientes:

"Artículo 41\%.- El Tribunal Constitucional conoce del Recurso Extraordinario Constitucional que se interponga en última y definitiva instancia contra las resoluciones de la Corte Suprema denegatoria de las acciones de garantía de Hábeas Corpus, Amparo, Hábeas Data y Acción de Cumplimiento. Pueden interponer el recurso el demandante, los terceros legitimados con apersonamiento previamente ad- 
mitido en el proceso, el Ministerio Público o el Defensor del Pueblo. (..)"

"CUARTO.- En tanto se aprueben las leyes orgánicas que regulen las acciones de garantía constitucionales previstas en los incisos 1, 2, 3 y 6 del Art. $200^{\circ}$ de la Constitución los procesos judiciales de Hábeas Corpus, Amparo, Hábeas Data y Acción de Cumplimiento se rigen por las leyes No 23506 , sus modificaciones y complementarias, y $\mathrm{N}^{\circ}$ 26301, en concordancia con las siguientes disposiciones:

1. Las acciones de garantía constitucional se interponen ante el Juzgado Civil o Penal según corresponda.

2. La Corte Superior conoce los procesos constitucionales de garantía en segunda y última instancia, en vía de apelación. Contra la resoluciones denegatorias de esta en materia de Hábeas Corpus, procede el recurso de casación constitucional ante la Sala Constitucional y Social de la Corte Suprema. Contra la Resolución de la Corte Superior, estimatoria o denegatoria, en materia de Amparo, Hábeas Data y Acción de Cumplimiento procede recurso de casación constitucional que prevee el Art. $35^{\circ}$ de la Ley No 23506, en los términos allí expresados.

3. Tratándose de la Acción de Hábeas Corpus, si la afectación de Derechos se origina una orden judicial el proceso se tramita conforme a lo previsto en el Art. $15^{\circ}$ de la Ley No 23506, con las modificaciones que contiene la Ley No 25398. Contra la resolución que expide la Sala Penal procede recurso de apelación ante la Sala Constitucional y Social de la Corte Suprema.

4. Tratándose de las acciones de Amparo, Hábeas Data, y Acción de Cumplimiento, si la afectación de derechos se origina en una orden judicial, el proceso se tramita conforme a lo dispuesto en el Art. $29^{\circ}$ de la Ley No 23506. Contra la resolución que expida la Sala Civil de la Corte Superior, procede recurso de apelación ante la Sala Constitucional y Social de la Corte Suprema.

5. Contra las resoluciones denegatorias que expida la Sala Constitucional y Social de la Corte Suprema, en materia de acción constitucional de Hábeas Corpus, Amparo, Hábeas Data y Acción de Cumplimiento, procede el Recurso Extraordinario de Revisión, de orden constitucional, ante el Tribunal Constitucional, que prevé el Art. $41^{\circ}$ de esta ley." 
Artículo $12^{\circ}$.- Deróguense o déjese en suspenso, según sea el caso, toda disposición legal en cuanto se oponga la presente ley.

Artículo $13^{\circ}$.- La presente ley entrará en vigencia al día siguiente de su publicación en el Diario Oficial «El Peruano». Será de aplicación inmediata a los procesos en trámite, aun cuando hayan sido sentenciados, en tanto no se encuentren ejecutoriados.

Los Recursos Extraordinarios de Revisión concedidos por las Cortes Superiores o la Corte Suprema ante el Tribunal Constitucional permanecerán allí hasta su instalación definitiva y correspondiente resolución .

DADO EN LA CASA DE GOBIERNO EN LIMA, A LOS [...] DIAS DEL MES DE [...]

EL PRESIDENTE CONSTITUCIONAL DE LA REPUBLICA

POR TANTO

MANDO SE PUBLIQUE Y CUMPLA

PRESIDENTE CONSTITUCIONAL DE LA REPUBLICA

PRESIDENTE DEL CONSEJO DE MINISTROS DE LA PRESIDENCIA

MINISTRO DE JUSTICIA 